\title{
Lipid Profile Changes of Elderly Males in Response to Aerobic Training and Detraining
}

\author{
Hosseini SA ${ }^{1}$, Salehi OR ${ }^{2}$, Farkhaie $\mathrm{F}^{3}$
}

\begin{abstract}
Introduction and purpose: In last two decades elderly population of iran increased. Aim of present study was to review the lipid profile changes of elderly males in response to aerobic training and detraining.

Materials and Methods: In this semi-experimental study 22 elderly males of yasuj city ferdows nursing home selected and base on their aerobic power divided in two groups of experimental and control. Experimental group trained aerobic exercise 8 weeks, 3 session per week and 30- 45 minutes with intensity of 55- 75 percent of maximum heart rate per session and after that detrained 2 weeks. For evaluate lipid profile blood samples gathered in week 1, 8 and 10. For statistical analysis of data used K$\mathrm{S}$, repeated measure ANOVA and bonferroni post hoc tests $(\mathrm{p} \unlhd) .05$ ).

Findings: 8 weeks aerobic training significantly reduces LDL $(\mathrm{p}=0.003)$, VLDL $(\mathrm{p}=0.007)$, TG $(\mathrm{p}=0.007)$, Cho $(\mathrm{p}=0.003)$ and increased HDL $(\mathrm{p}=0.001)$ of elderly males, nevertheless 2 weeks detraining significantly increased LDL $(p=0.001)$, VLDL $(p=0.001)$, TG $(p=0.002)$, Cholesterol $(\mathrm{p}=0.001)$ and decreased HDL $(\mathrm{p}=0.001)$ of elderly males.

Conclusion: Reduction of lipid profile following aerobic training and their increase with detraining, can represents this fact that useful and appropriate achievements of eight weeks aerobic training in elderlies who live in nursing home, will be destroyed by two weeks detraining.
\end{abstract}

Key words: Elderly, Lipids, Exercise, Detraining

Received: 2016/08/16

Accepted: 2017/02/4

Copyright $\odot 2018$ Quarterly Journal of Geriatric Nursing.This is an open-access article distributed under the terms of the Creative Commons Attribution international 4.0 International License(http://creativecommons.org/licenses/by /4.0/) which permits copy and redistribute the material, in any medium or format, provided the original work is properly cited.

1 - Department of Sport Physiology, Marvdasht Branch, Islamic Azad University, Marvdasht, Iran (Corresponding Author):E-mail: alihoseini_57@miau.ac.ir

2 - Department of Sport Physiology, Marvdasht Branch, Islamic Azad University, Marvdasht, Iran

3 - Department of Sport Physiology, Marvdasht Branch, Islamic Azad University, Marvdasht, Iran 


\title{
تغييرات يروفايل ليييدى مردان سالمند در ياسخ به تمرين هوازى و بى تمرينى
}

\author{
سيد على حسينى '، اميدرضا صالحى '، فاطمه فرخايى'
}

تاريخ دريافت مقاله: ع / ه/ هوسا

تاريخ يذيرش مقاله: ع| | | / هوس|

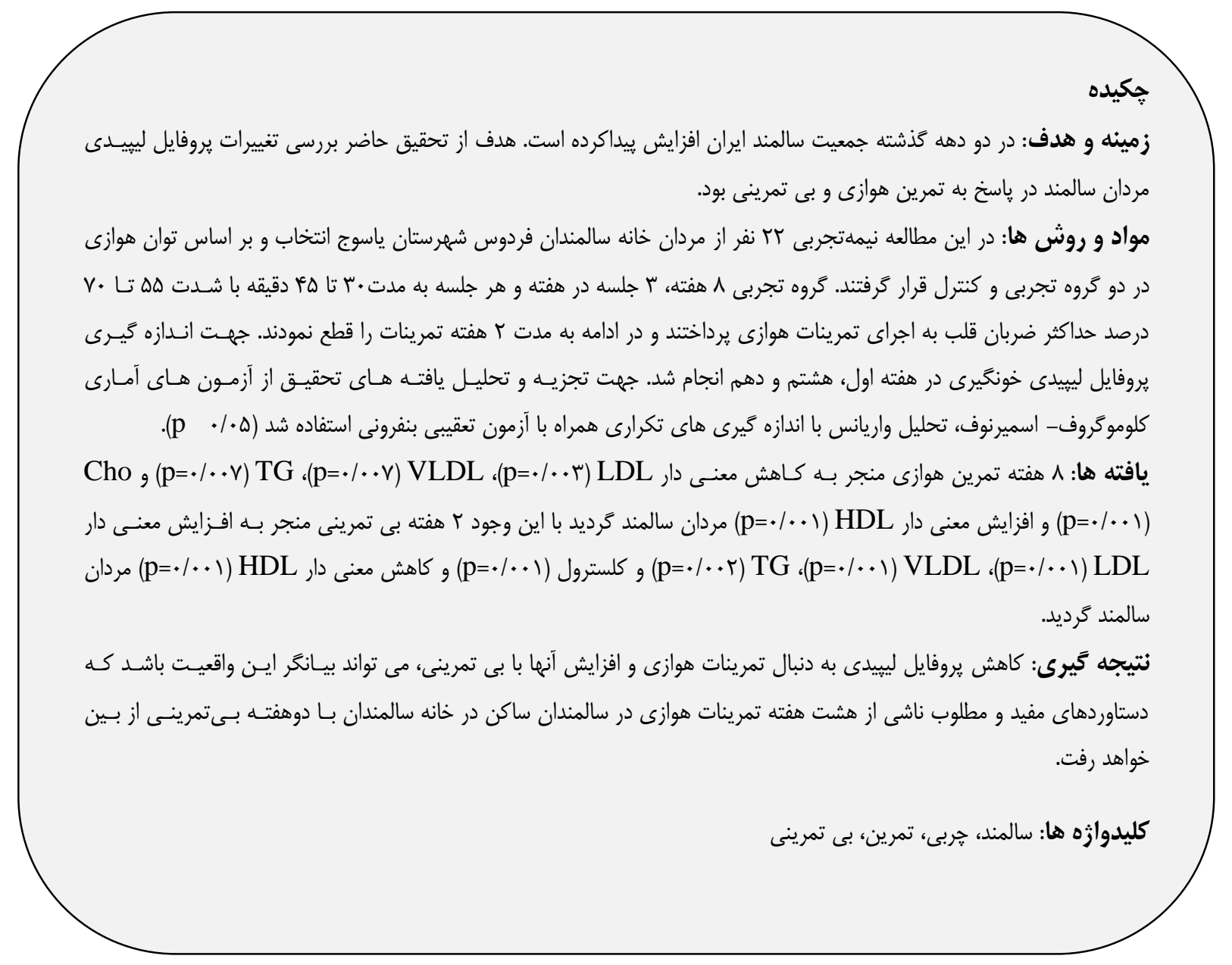

( 1 - كروه فيزيولوزى ورزشى، واحد مرودشت، دانشكاه آزاد اسلامى، مرودشت، ايران

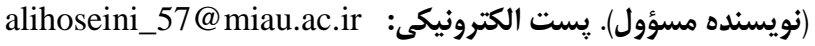

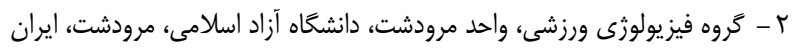

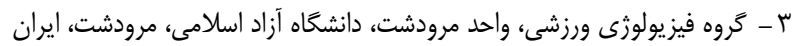


اخرجه بهترين شيوه مـديريت سـطوح غيـر طبيعى خربسى خـون، استفاده از داروها و برنامه غذايى مـى باشــ، داشـتن يـك برنامـهـ ورزشى هوازى منظم و اسـتاندارد مهـهم تـرين مولفـه يـك شـيوه زندگى سالم مى باشد (أ). فعاليت بدنى مناسـب و ورزش يكسى از كم هزينه ترين راه ها براى حفظ سلامت و ييشـحَيرى از بيمـارى هاى غير واگير از جمله فنار خون و قلبــ-عروقى اسـت و ايـن حقيقت كه فعاليت بدنى مناسب مى تواند باعث تندرستى، نشاط و شادابى انسان شود، مورد اتفاق نظـر همـهـ كارشناســان و خبرَّان حوزه سلامت است (ه). همجنين فعاليت هاى ورزشى منجـر بـــ بهبود وزن و تركيب بدنى سالمندان مى گَردد (ع) بـا ايـن وجـود كزارش شده است بيشتر از •م درصد جمعيت ايران از لحاظ بـدنى غيرفعال مى باشند (V). در حقيقت با افـزايش سـن توانـايى افـراد جهت اجراى فعاليت هاى روزانه زندكى تقليل مى يابــــ همـراه بــاـ افزايش سن كاهش فعاليت بدنى، افزايش كالرى دريافتى از طريق مصرف غذا و كاهش قابليت جابجايى جربى از ذخاير مربوطه منجر به افزايش سطوح درصد هربى بدن مى گردد، اين تغييرات درحالى است كه همزمان با آنها از ميزان توده بدون هربى كاسته مى شود.

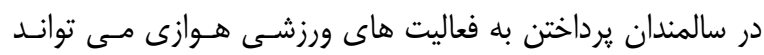
اكسايش جربــ را افـزايش و در مقابـل مقاومـت بـه انسـولين را كاهش دهد. از اينرو برنامه هاى كاهش وزن دربر گيرنده تمرينـات ورزشى مى تواند براى بهبود متابوليسم سوبستراى افراد سـالمند و קاق مناسب باشد (^). اكرجه يرداختن به فعاليت هاى ورزشى غالبا براى سالمندان دشوار مى باشد (V)، بـا ايـن وجـود تعـديل شـيوه زندكَى به وسيله ى افزايش فعاليـت ورزشـى يكـى از روش هـاى مؤثر در كنترل سلامتى به شمار مى آيد (9) به طورى كه فعاليـت
سالمندى تحت عنوان يكى بِديد زيسـت شـناختى و طبيعى مـورد يذيرش مى باشد (1). در دو دهل كذشته ساختار نسبى جمعت ايران به طور سريع و اشكار تغيير يافته است به طورى كه در سرشمارى سال •وسا جمعيت افراد بـالاى •ع سـال كشـور افـزون بـر N/ N

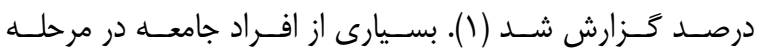
بازنشستخى زندگى خود، متاسفانه به دليل نامناسب بودن بعضى از شيوه هاى زندگى مانند كم تحركى و عدم فعاليت هـاى جسـمانى متوالى و مناسب، تغذيه نادرست، كمبود استراحت كـافى، كشـيدن سيخار و ....، عوامل خطـرزاى بيمـارى قلبـى - عروقى را در خـود افزايش داده و به همين دليل در سنين بالا بجاى آرامش، شادى و لذت بردن از زندگى در كنار خانواده براى رفع مشكلاتى مثل فشار خون، هربى خون بالا، قند خون بالا، ديابـت،رَفتكى عـروق و....، بايد دائما به يزشـك مراجعـه كـرده و جهـه بسـا كرفتـار معالجـات طولانى، مشقت بار و جراحى خواهند شد (T). كزارش شـده اسـت سالمندى و بالا رفتن سن مى تواند استرس اكسـيداتيو را افزايش داده و تعادل بين تشكيل و تخريسب راديكـال هـاى آزاد را از بـين ببرد و از اين طريق مى تواند تركيب جربى خون را تحت تاثير قرار

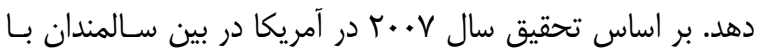

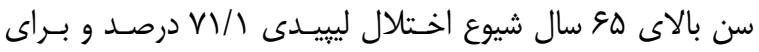
آقايان هو/ دوصد بوده است. اكرجه در ايران براى سالمندان آمـار خاصى وجود ندارد، به طور كلى بر اساس معيـار Adult ) ATP treatment panel كه براى تشخيص سندرم متابوليك مـورد استفاده مى باشد، ميزان شيوع سطوح بـالاى TV/^ TG درصــ و سطوح پايين V9/9 HDL درصد گزارش شده است (َّ). 


\section{مواد و روش ها - ماد}

در اين مطالعه نيمه تجربى و از نوع كاربردى بr نفر از سـالمندان خانه سالمندان فردوس شهرستان ياسوج كـه داوطلـب شـركت در تحقيق حاضر بودند، به عنوان نمونه آمارى انتخاب شــند. جهـــ اجراى تحقيق حاضر در ابتدا بــا نصــب اعلاميـهـ هــاى فراخـوان و دعوت به همكارى در خانه سالمندان فردوسى شهرسـتان ياسـوج، افرادى كه مايل به اجراى فعاليت ورزشـى بـراى بهبــود وضعيت فيزيولوزيك خود بودند، شناسايى گرديدند. در مرحله بعـد، از افـراد براى ارزيابى هاى اوليه دعوت به عمل آمد و از بين آن ها بr نفر داوطلب (با كنترل آنان از نظر عدم مصرف دخانيات، عدم اعتياد به مواد مخدر، عدم ابتلا به بيمارى هاى خاص از قبيل فشـار خـون، ديابت، بيمارى هاى قلبى- عروقى و هياتيت) انتخاب شدند. جلسه توجيحى در آغاز كار شامل معرفى كليـه شـرايط پـرُوهش اعـم از منافع و خطر هاى نادر احتمالى و توصيه هاى لازم براى هر يـى از آزمودنى ها بود و از آن ها رضايت نامه ایى براى شركت در تمام مراحل يُوهش اخذ شد. قبـل از آغـاز فعاليـت ورزشـى همجٍنـين يرسشنامه سلامتى، فرم رضايت نامه و اطلاعات عمـومى تكميـل شد. جهت همسان نمودن گروه هاى شـركت كنــده در يـروهش، يارامترهايى جون قد، وزن و توان هوازى (با استفاده از آزمون يك مايل راك يورت) به عمل آمده و سِّ آزمودنى ها بر اساس توان هوازى به دو گروه همسان تجربى و كنترل تقسـيم شـدند. گَروه تجربى طى تحقيق به اجـراى برنامـه تمرينسى يرداختــــ و حـروه كنترل نيز بدون مداخله به فعاليت هاى روزانه خود ادامه دادنـد. در اين تحقيق برنامه تمرين هوازى به مدت هشت هفتـه، هـر هفتـه

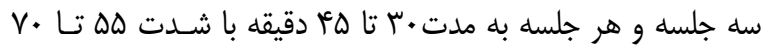
درصد حداكثر ضربان قلب اجرا شد. هر جلسه تمرين در تمام گروه
بدنى مى تواند از طريق كاهش شـاخص هـاى التهـابى، انعقـادى، سطوح جربى بدن عوامل خطرزاى قلبى- عروقى را كـاهش داده و در نتيجه مرك و مير افراد در معرض خطر را كاهش دهد (•(). در عصر كنونى بديده شهرنشينى منجر به افزايش اقامت سالمندان در خانه هاى سالمندان گرديده است به طورى كه اين عامل علاوه بر تغيير محل زندكى آنها تعاملات اجتماعى و فعاليت هاى بدنى آنها را تحت تاثير قرار مى دهد (1). در اغلب مطالعات صورت گرفتـه روى سالمندان، به بررسى اثرات فعاليت هـاى ورزشـى بـا شـــت، حجم و يروتكل هاى مختلف يرداخته شده است (צ- • (1) بـا ايـن وجود آنجه كه ضرورت اجراى تحقيق حاضر را بيشتر نمايان مسىكند، كمبود مطالعاتى است كه به بررسى اثرات بـى تمرينـى بــه دنبال يرداختن به فعاليت هاى ورزشى در يك دوره معين يرداختـه باشند. در حقيقت همراه با قطع تمرين و بى تمرينى ويزگى هـاى سودمند كسب شده ناشى از فعاليت هاى ورزشـى از بـين خواهنــــ رفت با اين وجود بستخى به مدت زمان بى تمرينى و نـوع فعاليـت هاى ورزشى صورت گرفته دارد. از اينرو با توجه به اينكه سالمندى يكى از حساس ترين دوره هاى زندَّى افراد اسـت و هـرداختن بــهـ احتياجات و نيازهاى اين مرحله داراى ضرورت اجتماعى مى باشـــ (1)، مطالعه حاضر با هدف بررسى اثرات هشـت هفتـه تمرينـات هوازى و دو هفته بى تمرينى بر تغييرات يروفايل ليييدى سالمندان ساكن در خانه سالمندان صورت كرفت. 
Cho توسط روش آنزيمى- كالريمترى با استفاده از دستخاه اتو

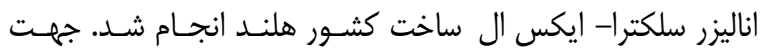

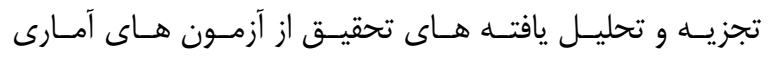
كلوموگروف - اسميرنوف، تحليل واريـانس بـا انـازه كيــى هـاى تكرارى همراه با آزمون تعقيبى بنفرونى استفاده شد (ه+/ p p).

\section{يافته ها}

در جدول ا ويزخى هاى جمعيت شناختى آزمودنى هـا ارائـهـ شــه است. سطوح يروفايل لييبدى مـردان سـالمند در هفتـه هـاى اول، هشتم و دهم در جدول r كَزارش شده است. نتايج آزمـون تحليـل واريانس با اندازه كيرى تكرارى نشـان داد تفـاوت معنى دارى در تغييــرات LDLL

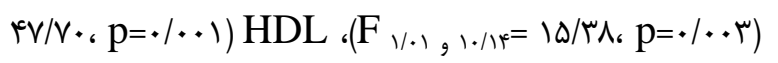

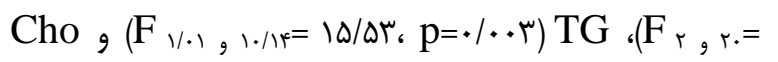

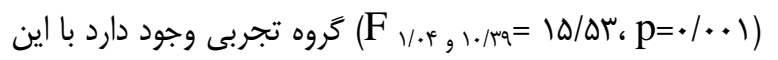
وجود تفاوت معنى دارى در تغييرات LDL $\mathrm{p}=\cdot / q \cdot) \mathrm{HDL}\left(\mathrm{F}_{r, r \cdot=}=/ \Delta r_{r} \mathrm{p}=\cdot / / r\right) \mathrm{VLDL} ،\left(\mathrm{~F}_{r}\right.$ Cho, $\left(F_{r, r \cdot}=r / \omega \cdot \bullet p=\bullet / 1 \cdot\right) T G$, $\left(F_{r, r \cdot}=\cdot / \cdot \bullet\right.$

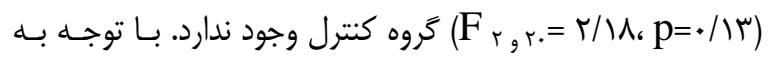
اينكه نتايج آزمون كرويت موخلى در رابطه بـا LLDL LDL،

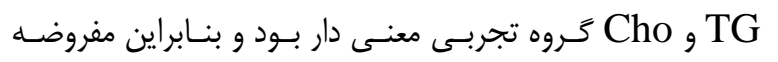
كرويت در اين نمونه هـا برقـرار نبـود، از عامـل اصـلاح إيسـيلون (اصلاحيه جى سر/ گَـرين هـاوس) جهـت تعـديل درجـات آزادى استفاده گَرديد. نتايج آزمـون تعقيبـ بنفرونس نشـان داد 1 هفتـه

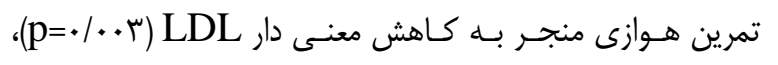

هاى تمرينى شامل سه مرحله بـود. () مرحلـه كـرم كـردن، ايـن مرحله شامل شش دقيقه دويدن آرام و جهار دقيقه حركات كششى و نرمش در هر جلسه بود كه مجموعاً تا ـا دقيقـه طـول كشـيد. r)مرحله تمرينات اختصاصى، برنامه تمرين هوازى شامل • بدقيقه دويدن با شدت هه تا هو درصد حداكثر ضربان قلب در جهار هفته اول در هر جلسه آغاز شد. ऍّ) مرحلـه سـرد كـردن، كـه در پايـان شامل سه تا جهار دقيقه دويدن نرم و راه رفتن و سپِ پنج دقيقه حركات كششى بعد از هر جلسه تمرين بود كه در كل زمان كمتـر از • ا دقيقه را به خـود اختصـاص مسى داد. بـراى كنتـرل شـدت تمرين، ضربان قلب تمرين براى تك تك افراد با گرَفتن نسبض در ناحيه مج دست و با استفاده از ضربان سنج يولار حسـاب شـد، بــه طورى كه حداكثر ضربان قلب از فرمـول بــرآورد حـــاكثر ضـربان

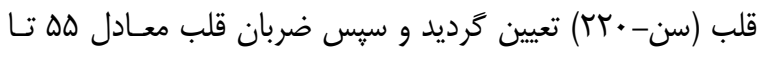
هو درصد حداكثر ضربان قلب براى هر شخص مشـخص كرديـد. پِ از جهار هفته براى رعايت اصـل اضـافه بـار مــدت تمرينـات هوازى به عץ دقيقه و شدت آن به هو تا •V درصد حداكثر ضربان قلب افزايش يافت. رزيم غذايى آزمودنى ها طبـق برنامـه غـذايى معمول هر شخص بود و هيجِكَونه داروى خاصى مصرف نكردنــ. جهت اندازه كَيرى يروفايل ليبيدى، پِ از ז ا ساعت ناشـتايى در مرحله ِيش آزمون و پس از آخرين جلسه تمـرين در مرحلـه يـس آزمون، به مقدار ه سى سى خــون از وريــد دسـت هـ

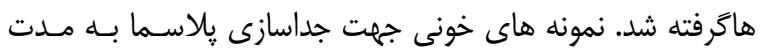
ها دقيقه با سرعت ...r دور در دقيقه سانتريفيوز شده و در دماى •ــ درجه سانتى كراد منجمد، و براى آنـاليز هـاى بعـدى ذخيـــه شد. اندازه كيرى سطوح LDDL و آنزيمى كلـوكز اكسـيداز (زيسـت شـيمى) و انــازه كيـرى TG و 


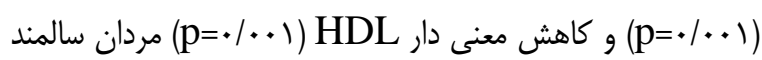

كرديد.

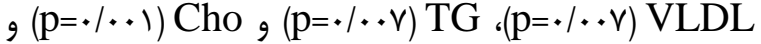

افزايش معنى دار HDL HD H مردان سالمند كرديد با ايـن

وجود r هفتـه بـى تمرينس منجـر بــه افزايش معنى دار LDL

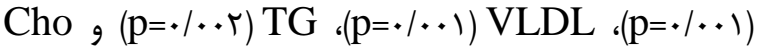

جدول (. ويزتى هاى جمعيت شناختى ازمودنى ها (متغيرها بر اساس انحراف استاندارد ـ ميانكين كزارش شده اند)

\begin{tabular}{|c|c|c|}
\hline \multicolumn{2}{|c|}{ تروه } & \multirow[t]{2}{*}{ متغيير } \\
\hline كنترل & تجربى & \\
\hline$\varepsilon N / \cdot \pm \pm / r$. & $\varepsilon N / F \Delta \pm \Psi / q$. & سن (سال) \\
\hline$|V \mathcal{C} / \Lambda| \pm q / r \mu$ & $\left|V^{\top} / q \cdot \pm N / 1\right|$ & قد (سانتى متر) \\
\hline$V / \mathscr{T} \Delta \pm N / N G$ & $V T / T Y \pm 1 \cdot / \Delta$. & وزن (كيلوَّرم) \\
\hline
\end{tabular}

جدول r. سطوح يروفايل ليبيدى تروه هاى تحقيق در هفته اول، هشتم و دهم (مقياس تمام متغييرها mg/dl است.

\begin{tabular}{|c|c|c|c|c|}
\hline هفته دهم & هفته هشتم & هفته اول & كروه & متغيير \\
\hline ৭৭/я $\pm r V / • \Lambda \ddagger$ & 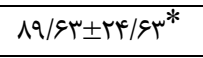 & $\mid r \Delta / V T \pm T r / M \Lambda$ & تمرين هوازى & LDL \\
\hline $1 \cdot \Delta / r \Lambda \pm m r / \kappa q$ & $1 \cdot r / f \Delta \pm r \cdot|\Delta|$ & $1 \cdot r / r V \pm r q / r q$ & كنترل & \\
\hline$r r / r V \pm 1 Q / 9 r \ddagger$ & $r q / \wedge 1 \pm \mid \Delta / . q^{*}$ & Er/rg士rr/אq & تمرين هوازى & VLDL \\
\hline$r N / 11 \pm q / r \varepsilon$ & 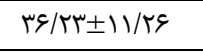 & 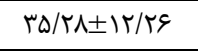 & كنترل & \\
\hline$\Gamma \Delta / \cdot \cdot \pm \Delta / \& V$ & $\uparrow q / r \varepsilon \pm \Delta / q \Lambda \dagger$ & $r \cdot / \Lambda \Lambda \pm \varepsilon / / r$ & تمرين هوازى & HDL \\
\hline$r q / r r \pm \varepsilon / r)$ & $F Y / D F \pm V / F F$ & $f \cdot / f \Delta \pm V / \Delta \varepsilon$ & كنترل & \\
\hline $19 \cdot / 1 \Lambda \pm \Lambda \cdot / 8 \Lambda \ddagger$ & $1 \uparrow N / q \cdot \pm V \Delta / \Delta \cdot *$ & $r \| / \& \Psi \pm I I V / V V$ & تمرين هوازى & TG \\
\hline $\mid V q / \cdot q \pm \Delta Q / \varepsilon r$ & $\mid V \& / \cdots \pm \Delta \Lambda / V \Delta$ & $|\mathrm{VV} / \cdot \pm \pm g| / \mathrm{Fq}^{2}$ & كنترل & \\
\hline$|V \varphi / \Lambda| \pm r \cdot / q \varepsilon \dagger$ & $\mid \& V / \backslash \Lambda \pm r r / . . *$ & $r \cdot \varepsilon / \cdot 9 \pm r N / 19$ & تمرين هوازى & Cho \\
\hline$|\Lambda| / \Delta T \pm F \Delta / M$ & $\mid V V / q r \pm f r / q r$ & 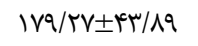 & كنترل & \\
\hline
\end{tabular}

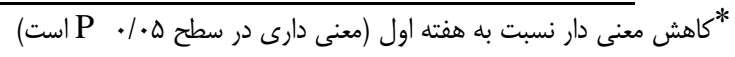

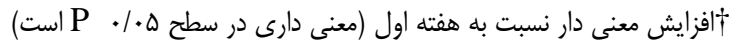

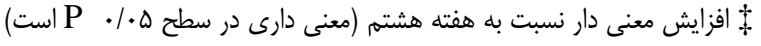

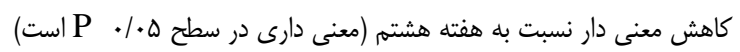




\section{بحث و نتيجه كَيرى}

و دو هفته بى تمرينى منجر بله برگشـت سـطوح بهبـود يافتـه بــه حالت اوليه گرديد. در مطالعات مختلفى به بررسـى اثرات فعاليـت هاى ورزشى بر يروفايل ليبيدى سالمندان يرداخته شده اسـت كـهـ نتايج آنها مبنى بر اثرات مثبـت فعاليـت هـاى ورزشـى بـر بهبـود يروفايل ليييدى سالمندان است. براى مثال گزارش شد 1 هفتـه، ؟ جلسه در هفته و هر جلسه يك ساعت تمرين هوازى با شـدت هـا تا •ع درصد ضربان قلب بيشينه منجر به كـاهش معنـى دار TG، و CDL مقاومتى يـيش رونــده منجــر بـهـ كـاهش معنـى دار Cho (س/سا درصد) و TG T/T T/ درصد) بزر گسالان مبـتلا بـه ديابـت نـوع r T

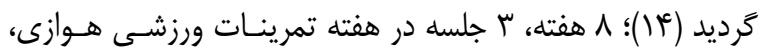
همزمان (هوازى و مقاومتى) و مقاومتى (با شدت ييش رونده از •ه درصد به •1 درصد يك تكرار بيشينه) منجر به كـاهش معنـى دار Cho كاهش معنى دار Cho، TDL ، TG و افزايش معنى دار HDL بيماران مبتلا به ديابت گرديد (عا)؛ | (ا هفته، س جلسه در هفتـه و هر جلسه · r دقيقه تمرينات ويبريشن و همجٍنين مقـاومتى منجــر بـه كـاهش معنسى دار TC و TC و TCL و افـزايش معنسى دار مردان سالمند با دامنه سنى • •و تا •V سـال گرديسـ (IVL)؛ •1 هفته، ب جلسه در هفته و هر جلسه 1 حركت ورزش مقـاومتى اثر معنى دارى بر HDL و THL مردان خاق نداشـت بـا اين وجود منجر به كـاهش معنسى دار Cho مـردان جـاق كرديـد

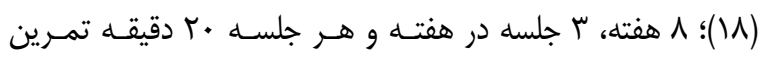
هوازى با شدت •ه درصد ضربان قلب بيشـينه همـراه بـا مصـرف مكمل عصاره دانه انكًور منجر به كاهش معنى دار LDL ، TG و
روند سالمندى به دليل جاقى و شيوه ى زندگى غير فعال، افـراد را در معرض عوامل تهلديد كننده ى جدى سلامت قرار مسى دهـد. از زمان هاى كذشته يروفايل ليييـدى تحـت عنـوان ابـزار اسـتاندارد شناسايى افرادى كه در معرض خطر بيمارى هاى قلبى- عروقى مى باشند، استفاده مى شد در جامعه كنونى نيـز ايـن شـاخص هـا جهت هدف هاى تشخيصى استفاده مى شود (YI). بيمـارى هـاى قلبى- عروقى كه مهمترين آن ها آترواسكروز است، علـت اصـلى مرگ و مير و ناتوانى در اكثر كشورهاى صنعتى و يِيشـفته جهـان به شمار مى روند. از اينرو شناسايى عوامل خطرساز بيمـارى هـاى قلبى - عروقى در درمان و ييشخيرى از ييشرفت بيمارى و كـاهش هزينه هاى درمانى اهميت فراوانى دارد. در كنـار عوامـل شـناخته شده اى مانند سيخار، سن، جـنس، يرفشـارخونى، جـاقى، افـزايش يروفايل ليييدى، عدم تحرك و نداشتن فعاليت بدنى مناسب نيـز از عوامل خطر قابل كنترل بيمارى هاى عروقى كرونـرى اسـت كـهـ سال هاست توجه فيزيولوزيست ها، يزشكان و متخصصين قلب را به خود جلب كرده است. بـدون شـك عـادت بــه تمرينـات بـدنى مناسب و سطح آمادگى جسمانى بالا مـى توانـــ عامـل مهمسى در ييشگيرى و كاهش شدت امراض مختلف بين مردم سراسر جهـان باشد (سا). نتايج تحقيق حاضر نشـان داد هشـت هفتـه تمرينـات

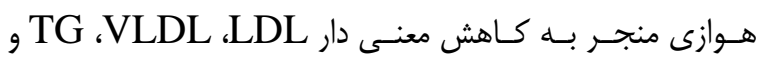
و ومهُجنين افزايش معنى دار HDLo در خانه سالمندان گَرديد با اين وجود بعد از دو هفتـه بسى تمرينسى

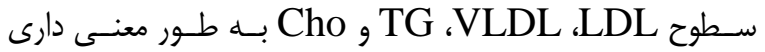
افزايش و HDL به طور معنى دارى كاهش يافت بدين معنى كه تمرين هوازى منجر به بهبود يروفايل ليييدى مردان سالمند گرديد 
انسولين كه تغييراتى در سطح هربى ها و لييويروتئين هاى خـونى

ايجاد مى كند، مى تواند در اين زمينه تاثير كذار باشد (آ).

در تاييد اثرات سودمند قعاليت هاى ورزشى بـر يروفايـل ليييـدى

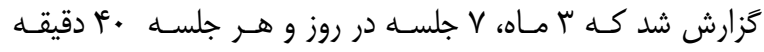

تمرينـات تـاى جـى منجـر بــه كـاهش معنسى دار TC TC و

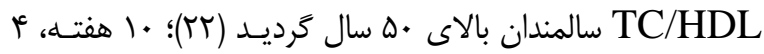

جلسه در هفته انجام تمرينات ورزشى دنس منجر به بهبــود معنى

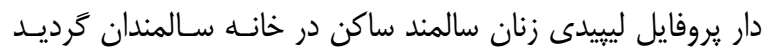

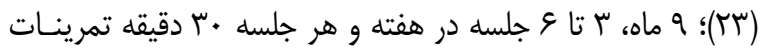

هوازى با شدت متوسط اثر معنى دارى بـر TC و TC TC نداشت با اين وجود منجر بــهـ افـزايش معنسى دار HDL زنـان و

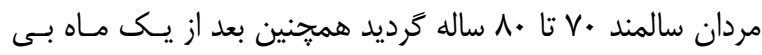
تمرين HDL به طور معنى دار كاهش يافت (ז)؛؛ 1 هفته تمرين هوازى (برنامه تمرين هوازى شامل دويدن با شدت كار ه广 تـا هـ درصد ضربان قلب ذخيره اى به مدت 1 دقيقه در هفتـه اول بـود كه به •و درصد ضربان قلب ذخيره اى به مدت •r دقيقه در هفته هشتم رسيد) منجر به افزايش معنى دار HDL و كاهش معنى دار زنان سالمند جاق گَرديد (זه)؛ يك سال تمرينات ورزشى منحر به كاهش معنى دار كلسترول و همرِنين افزايش معنس دار

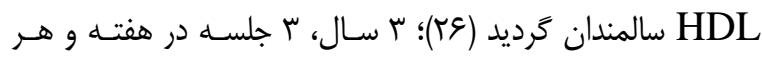
جلسه •ه دقيقه تمرينات هوازى و مقاومتى منجر به كاهش معنى دار TC و افز ايش معنسى دار HDL زنـان سـالمند كَرديــ (TV)

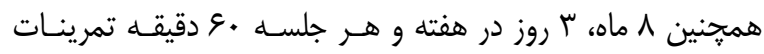
ورزشى منتخب منجر به كـاهش معنى دار TC/HDL TG و افزايش معنى دار HDL در مردان سالمند •ع تا •م سـاله ترديــد (ケ^). تناقض در نتايج مطالعات مى تواند ناشى از عوامل مختلفى

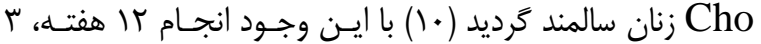
جلسه در هفته و هر جلسه • ا تا •r دقيقه تمرينات پٍله ورزشى در حد استانه لاكتات در خانه اثر معنى دار بر يروفايـل ليييـدى زنـان سالمند ه\$ تا هم ساله نداشت (19). در رابطه با اثـر فعاليـت هـاى ورزشى بر يروفايل لييبدى كزارش شده است HDL يـك نقـش بسيار مهم را در مسير حمل و نقل كلسـترول دارد و مقـدار آن بـاــا توجه به مقدار و شدت تمرين افزايش مسى يابـد. همجنــين رابطهـ افزايش HDL يلاسما با كاهش وزن و ترى كليسـيد קِلاسـماى بلن در هندين مطالعه گزارش شده است كه در ظاهر اين منجر به

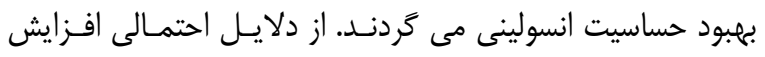
(Lipoprotein Lipase) LPL افزايش فعاليت آنزيم HDL در نتيجه فعاليت ورزشى مسى باشـــ. در حقيقـت آنـزيم LPL در تبديل VLDL به HDL موثر است و بــا افـزايش فعاليـت آن، Lecithin- ) افزح HDL LCAT ايش مى يابد. از طرفى (Cholesterol Acyltransferase علاوه بر LDL، كلسترول را به ذرات HDL تبديل مى كند. ممكن است افزايش اين آنزيم مسئول افزايش HDL ناشى از تمرين باشد. نشان داده شده است كه LCAT به ميزان زيادى در بعضى از تمـرين هـاى ورزشى افزايش داشته است. همجنين به نظر مى رسد فعاليت هاى ورزشى سبب افزايش لييوليز و كاهش اسيدهاى جرب در خود عضلات نيز مى شـوند (·r). بــهـ طـورى كـه افـزايش فعاليـت LPL تجزيـه كليسرول در VLDL را تسريع مى كند و موجب حذف ذره هـاى لييويروتئينى مى شود. علاوه بر اين علت احتمـالى ديخــر افزايش HDL افزايش توليد HDL توسط كبد در بى تغييـرات فعاليـت آنزيم LPL و كاهش ليياز كبدى به دنبال فعاليت بدنى مى باشد. احتمال مى رود مكـانيزم هـاى ديخــرى مثـل كـاهش حساسـيت 


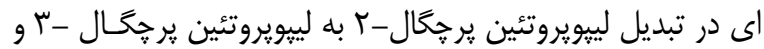
تبديل LDL به ليبويروتئين ميان جُال ايفا مى كند. مقــار ايسن آنزيم در افراد فعال كم است و بر اثـر فعاليـت ورزشـى ميـزان آن كاهش بيشـترى يافتـه و باعـث حفـظ غلظـت HDL در مقــدار زيادترى مى شود (با). اين تغييـرات آنزيمسى كـهـ در اثـر فعاليـت ورزشى رخ مى دهد، مى تواند موجب بهبود يروفايل ليبيدى شـود. احتمال مى رود تمرينات هوازى مورد استفاده در تحقيق حاضـر بــاــا مكانيسم مذكور منجر به بهبـود يروفايـل ليييـدى مـردان سـالمند ساكن در خانه سالمندان گرديده است. تحقيقات انجام شده بيـانگَر آن اسـت كـه دسـتاوردهاى ناشـى از تمـرين در دورهى بـى تمرينسى از بـين مسى رود و تفـاوتى بـين ورزشكاران بى تمرين با افراد غير فــال از نظـــ آمـادگى و سـطح سلامت، ديده نمى شود (آّ). گزارش شـده اسـت بسى تمرينسى و كاهش فعاليت بدنى كه خود مسى توانـــــــر اثر عـواملى از جملـه شرايط اجتماعى حاكم بر جوامع امروزى كه افراد را به سـوى كـم تحركى سوق داده، قطع تمرين، آسيب ديدگى، فرايند سـالمندى و ... باشد، بر يروفايل ليييدى مؤثر است (ז با). در همين راستا نتـايج تحقيق حاضر نشان داد كه با دو هفته بسى تمرينسى دستاوردهاى بهبود يافته يروفايل ليييدى مردان سالمند با دو هفته بى تمرينى از بين رفته است. همسو با نتايج تحقيق حاضر نشان داده شده اسـت كه عدم تعادل دريافت و مصرف انرزى كه بر اثر بى تمرينى و بسى تحركى صورت مى كيرد و با افززايش وزن و جـاقى افـراد همـراه است، سبب افزايش خربى هاى خون مى شـود (Tس). بنـابراين، بــا توجه به يافته هاى اين بزوهش مى تـوان اينكَونـهـ نتيجـهـ كيــى نمود كه كاهش يروفايـل ليبيـدى بــهـ دنبـال تمرينـات هـوازى و

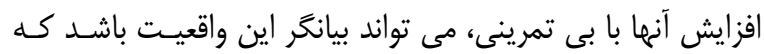

از قبيل نوع فعاليت ورزشى، شــت فعاليـت، حجـم فعاليـت، نـوع آزمودنى (سالم در مقابل بيمار بـودن)، محـل زنــدى و همجنـين سطوح קايه يروفايل لييبدى باشد. همجنين فعاليـت هـاى ورزشىى هوازى با توجه به ماهيـت كاهنــده وزن بيشـتر، اثـر بيشـترى بـر كاهش بروفايل لييبيدى نسبت بــه تمرينـات مقـاومتى دارنـــ (وَ). علاوه بر موارد مذكور نشان داده شده كه تغييرات HDL به دنبال فعاليت هاى ورزشى تحت تاثير زنتيك، شدت و مدت فعاليت هاى ورزشى قرار مى گيرد. فعاليت ورزشى بـر شـكل گيــى HDL و تركيب آن، جريان ورودى كلسترول و تحويل كلسترول به كَيرنـده اثر كذار است (f). همجِنين كزارش شده است در افرادى كـه داراى سطوح يروفايل ليبيـدى بـالاتر از سـطح نرمـال باشــ، اثركــارى تمرينات ورزشى بر كاهش اين عوامل بيشـتر مس باشـــ (•). بـا مقايسه سطوح بايه بروفايل لييبدى آزمودنى هاى تحقيق حاضر بـاـ آزمودنى هاى تحقيق آتشـى و همكـاران مشـاهده مسى كـردد در

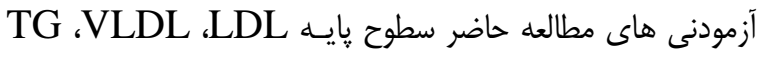
و Cho بالاتر و سـطح HDL كمتـر از آزمـودنى هـاى مطالعـه مذكور مسى باشـــ (1).. از دلايـل عـدم همسـويى نتـايج مطالعـه Tanakaa كمتر تمرينات تجويز شده در هر جلسه (•ا تا •ب دقيقه در مقابـل • ب تا هو دقيقه) باشد (19) به طورى كه بـا افـزايش مـدت زمـان. تمرين ميزان كالرى مصرفى افزايش يافته و در مقابـل مسى توانـــ اثرات بيشترى بـر كـاهش وزن، تـوده هربـى و متقــابلا يروفايـل ليييدى داشته باشد (•r). به نظر مى رسد كه علت افزايش HDL مى تواند افزايش توليد آن در كبد و تغيير در آنـزيم هـاى مختلـف مانند لستين كلسترول آسيل ترانسفراز و كاهش فعاليت ليياز كبدى به دنبال فعاليت هاى ورزشى باشد. آنزيم ليياز كبدى نقـش عمـده 


\begin{tabular}{|c|c|}
\hline تشكر و قدردانى & دستاوردهاى مفيد و مطلوب ناشى از هشت هفته تمرينات هــوازى \\
\hline در پايان نويسنده مراتب قدردانى خود را از تمامى آزمودنى هاى كه & در سالمندان ساكن در خانه سالمندان با دو هفته بى تمرينى از بين \\
\hline در تحقيق حاضر شركت نمودند و جناب آقاى مهدى جمشيدى كه & 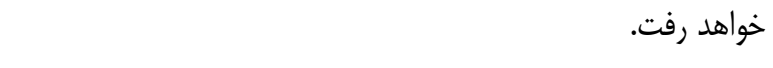 \\
\hline
\end{tabular}

- References

1. Rezaei B, Shooshtarizadeh S. Factors Related to Sleep Quality among Elderly Residing at Isfahan Nursing Homes. JGN. 2016; 2 (2): 37- 49.

2. Aldrich N, Benson W. Disaster Preparedness and the Chronic Disease Needs of Vulnerable Older Adults. Prev Chronic Dis. 2008; 5 (1): 27.

3. Malekahmadi M, Alavi Naeini A, Djazayery A, Aghaye ghazvini M. The Combined Effect of Vitamins E and C Supplementation on the Lipid Profiles of Elderly Residents in Isfahan. Iranian J Nut Sci Food Tech. 2015; 10 (2): 37- 46.

4. Trejo-Gutierrez JF, Fletcher G. Impact of Exercise on Blood Lipids and Lipoproteins. J Clin Lipidol. 2007; 1: 175- 181.

5. Sadeghi-Bazargani H, et al. Risk Factor Investigation for Cardiovascular Health through WHO STEPS Approach in Ardabil, Iran. Vasc Health Risk Manag. 2011; 7 (4): 17- 24.

6. Kazemi A, Ghanbarzadeh M. Comparison of Different Concurrent Training on Physical Performance and Components of Body Composition in Elderly. JGN. 2015; 2 (1): 19- 28.

7. shakerinia I, Ramazani F. The Relationship between Physical Exercise, Religious Beliefs and Happiness in Older Women. JGN. 2016; 2 (2): 25- 36.

8. Faramarzi M, Aghababa R. The Effects of Omega-3 Fatty Acid Supplementation and Aerobic Exercise on Adiponectin and Insulin Resistance of Older Women. J Sport Biomotor Sci. 2012; 5 (1): 56- 66. 
9. Saremi A, Shavandi N, Parastesh M, Daneshmand H. Twelve-week Aerobic Training Decreases Chemerin Level and Improves Cardiometabolic Risk Factors in Overweight and Obese Men. Asian j Sports Med. 2010; 3 (1): 151- 158.

10. Saedmocheshi S, Almori M R, Saedmocheshi L. Interactive Effect of Grape Seed Extract Along with Aerobic Activity on Lipid Profile in Inactive Obese Women Aged Over 60 Years Sanandaj. IJDLD. 2015; 14 (4): 273- 278.

11. Taheri N, Fereydouni moghaddam M, Cheraghian B, Hekmati pour N, Hojjati H. Factors Affecting Quality of Life among Elderly Living in Nursing Homes. JGN. 2015; 2 (1): 5061.

12. Ghafari G, Bolboli L, Rajabi A, Saedmochshi S. The Effect of 8 Weeks Aerobic Training on Predictive Inflammatory Markers of Atherosclerosis and Lipid Profile in Obese Elderly Women. Ilam Med Sci Uni J. 2016; 23 (7): 144- 154.

13. Khalesi M, Gaieni AA, Shabkhiz F, Samadi A, Tork F. The Effect of a Period of Discontinuous Endurance Exercise on ICAM-1 and Lipid Profile of Non-athletic Male Students. Sabzevar Med Sci J. 2011; 18 (3): 198- 205.

14. Arora E, Shenoy S, Sandhu JS. Effects of Resistance Training on Metabolic Profile of Adults with Type 2 Diabetes. Indian J Med Res. 2009; 129: 515- 519.

15. Ghahramanloo E, Midgley A, McNaughton LR, Bentley DJ. Effect of Concurrent Training on Blood Lipid Profile in Untrained Men. Med Sci Sports Exerc. 2009; 41 (5): 138- 139.

16. Cauza E, Hanusch-Enserer U, Strasser B, Ludvik B, Metz-Schimmerl S, Pacini G. The Relative Benefits of Endurance and Strength Training on the Metabolic Factors and Muscle Function of People with Type 2 Diabetes Mellitus. Arch Phys Med Rehabil. 2005; 86 (8): 1527- 1533.

17. Bakheet EN, Serry ZM, Mohamed ME. Impact of Whole Body Vibration Versus Resistive Exercise Training on Lipid Profile in Elderly. World J Med Sci. 2016; 13 (1): 1- 8.

18. Atashak S, Jafari A, Azarbayjani M A. The Influences of Long-term Resistance Training on Adiponectin and Lipid Profiles Levels in Obese Men. RJMS. 2011; 18 (86): 1 - 11.

19. Nishidaa Y, Tanakaa K, Haraa M, Hiraob N, Tanakab H, Tobinac T, Ikedad M, Yamatoe H, Ohtae M. Effects of Home-based Bench Step Exercise on Inflammatory Cytokines and Lipid Profiles in Elderly Japanese Females: A Randomized Controlled Trial. Arch Gerontol Geriatr. 2015; 61: 443- 451. 
20. Delevatti R, Marson E, \& Fernando Kruel L. Effect of Aquatic Exercise Training on Lipids Profile and Glycaemia: A Systematic Review. Rev Andal Med Deporte. 2015; 8 (4): 163170.

21. Eatemady-Boroujeni A, Kargarfard M, Mojtahedi H, Rouzbehani, R \& Dastbarhagh H. Comparison of the Effects of 8-Weeks Aerobic Training and Resistance Training on Lipid Profile in Patients with Diabetes Type 2. Isfahan Med Univ J. 2014; 32: 524- 533.

22. Lu WA, Kuo C. Three Months of Tai Chi Chuan Exercise Can Reduce Serum Triglyceride and Endothelin-1 in the Elderly. Complement Ther Clin Pract. 2013; 19: 204- 208.

23. Kim S, June K, Song R. Effects of Nutrition Education and Exercise Programs on Perceived Dietary Behaviors, Food Intake and Serum Lipid Profiles in Elderly Korean Women Living in Residential Homes. Asian Nurs Res (Korean Soc Nurs Sci). 2007; 1 (1): 35- 47.

24. Motoyama M, Sunami Y, Kinoshita F, Irie T, Sasaki J, Arakawa K, Kiyonaga A, Tanaka H, Shindo M. The Effects of Long-term Low Intensity Aerobic Training and Detraining on Serum Lipid and Lipoprotein Concentrations in Elderly Men and Women. Eur J Appl Physio. 1995; 70: 126- 131.

25. Namazizadeh M, Fathollahi F, Jalali K, Sheikh saraf B. Effects of 8 Weeks Aerobic Training on Changes Rate, Omentine-1, Insulin Resistance, CRP and Lipid Profile in Overweight and Obese Elderly Women. J Sport Med Phys Fit. 2014; 1 (1): 1 - 20.

26. Lobo A, Carvalho J, Santos P. Effects of Training and Detraining on Physical Fitness, Physical Activity Patterns, Cardiovascular Variables, and HRQoL after 3 Health-Promotion Interventions in Institutionalized Elders. Int J Famili Med. 2010; 48: 1- 10.

27. Kosmidou KV, Douda HT, Eleftheriadou AI, Volaklis KA, Tokmakidis SP. The Effect of a 3-year Combined Exercise Program on Body Composition and Lipid Profile in Elderly Women. Arch Hellen Med. 2014; 31 (2): 191- 199.

28. Carvalho J, Marques E, Ascensa A, Magalha es J, Marques F, Mota J. Multicomponent Exercise Program Improves Blood Lipid Profile and Antioxidant Capacity in Older Women. Arch Gerontol Geriatr. 2010; 51: 1- 5.

29. Kostka T, Lacour JR, Bonnefoy M. Response of Blood Lipids to Physical Exercise in Elderly Subjects. Prev Cardiol. 2001; 4 (3): 122- 125. 
30. Delevatti R, Marson E, FernandoKruel L. Effect of Aquatic Exercise Training on Lipids Profile and Glycaemia: A Systematic Review. Rev Andal Med Deporte. 2015; 8 (4): 163170.

31. Adamopoulos S, Parissis J, Kroupis C. Physical Training Reduces Peripheral Markers of Inflammation in Patients with Chronic Heart Failusre. Eur Heart J. 2001; 22 (9): 791- 797.

32. Mogharnasi M, Gaieni AA, Kordi M, Ravasi E, Javadi A, Sheikholeslami D. The Effect of Four Weeks of Detraining after a Period of Intense Sprint Training on Risk Factors of Atherogenic Inflammatory Damages. Sport Bio Sci J. 2011; 9: 5- 20. 